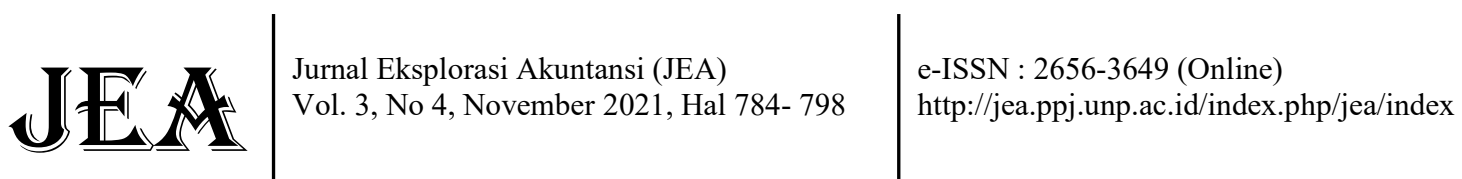

\section{Pengaruh Karakteristik Dewan Pengawas Syariah (DPS) Terhadap Kinerja Keuangan Bank Umum Syariah Yang Terdaftar pada Otoritas Jasa Keuangan (OJK) Indonesia}

\author{
Lila Afiska ${ }^{*}$, Dian Fitria Handayani ${ }^{2}$, Vanica Serly ${ }^{3}$ \\ ${ }^{1,2,3}$ Fakultas Ekonomi, Universitas Negeri Padang \\ *Korespondensi: lilaafiska144@gmail.com
}

\begin{abstract}
This paper investigated the effect of the characteristics of the Sharia Supervisory Board (SSB) on the financial performance of Islamic banks listed in Financial Service Authority of Indonesia (OJK) during the period 2016-2020. SSB characteristics consist of size, number of meeting, educational qualification, and reputation. Using purposive sampling, we obtained samples from 13 Islamic Banks in Indonesia. Data was collected from annual report of selected banks for the year 2016-2020 and has been analyzed using the multiple linear regression. The results show that educational qualification of SSB members have significant positive effect on the financial performance. While size, the meeting and reputation of SSB members had no significant effects on the financial performance. This paper gives a comprehensive literature survey on the effect of the characteristics of the Sharia Supervisory Board (SSB) on the financial performance and robustness checks provides support for the findings.
\end{abstract}

Keywords: Financial performance; Islamic banks; ROA; Sharia supervisory board.

How to cite (APA $6^{\text {th }}$ style)

Afiska, L., Handayani, D. F., \& Serly, V. (2021). Pengaruh Karakteristik Dewan Pengawas Syariah Terhadap Kinerja Keuangan Bank Umum Syariah Yang Terdaftar pada Otoritas Jasa Keuangan (OJK) Indonesia. Jurnal Eksplorasi Akuntansi (JEA), 3 (4), 784-798

\section{PENDAHULUAN}

Perkembangan Bank Syariah di Indonesia saat ini mengalami perkembangan yang pesat. Adanya landasan kuat yang di atur dalam Undang-Undang No. 21 Tahun 2008 tentang perbankan syariah merupakan salah satu faktor penyebab perkembangan perbankan syariah di (Fajriyah \& Jumady, 2021). Selain itu, Indonesia merupakan negara muslim terbesar di dunia sehingga keinginan masyarakat untuk menggunakan fasilitas dan jasa yang ditawarkan bank syariah cukup tinggi yang kemudian berdampak kepada pertumbuhan dan perkembangan bank syariah di Indonesia.

Dibalik perkembangan perbankan syariah yang dinilai cukup baik, ternyata kinerja perbankan syariah masih berada dibawah bank konvensional. Bank syariah masih memiliki beberapa permasalahan dalam perkembangannya, dimana permasalahan tersebut berasal dari internal bank syariah itu sendiri. Permasalahan tersebut adalah karyawan bank syariah yang masih minim akan pengetahuan dan pemahaman terhadap perbankan syariah dan ekonomi 
islam. Sehingga, adanya anggapan masyarakat, bahwa kinerja bank syariah tidak sebaik kinerja bank konvensional (Hasan, 2009). Dominasi Bank Konvensional masih besar, hal ini terlihat pada keberadaan bank konvensional hingga ke lokasi terpencil dan terdalam (Vivin \& Wahono, 2017). Masyarakat masih bergantung dengan sistem konvensional. Masyarakat jauh lebih mengenal sistem bank yang berbentuk suku bunga dibandingkan sistem bank bagi hasil. Kondisi ini tentunya menuntut bank syariah untuk terus meningkatkan kinerjanya agar bisa bersaing dengan bank konvensional.

Kinerja bank adalah salah satu faktor penting yang harus diperhatikan oleh bank agar bisa terus bertahan hidup (Putri, Fadah, \& Endhiarto, 2010). Kinerja keuangan bank merupakan bagian dari kinerja bank secara keseluruhan. Kinerja keuangan merupakan gambaran capaian hasil ekonomi dari kegiatan operasional yang dilakukan bank syariah untuk mendapatkan keuntungan secara efektif dan efisien dalam waktu tertentu. Kinerja keuangan menjadi pertimbangan yang signifikan bagi pihak yang berkepentingan pada bank (Umardani \& Muchlish, 2017). Bagi investor, kinerja keuangan merupakan faktor penting dalam menentukan keputusan investasi. Jika kinerja keuangan bank baik maka harga saham akan meningkat sehingga investor tertarik untuk menanamkan modalnya di bank tersebut. Bagi bank, kinerja keuangan digunakan manajemen untuk melakukan penilaian secara periodik mengenai operasional suatu bank berdasarkan standar kinerja yang telah ditetapkan (Trilestari, 2020). Pengukuran kinerja keuangan bank berguna sebagai alat pengendalian dan evaluasi atas kegiatan operasional bank. Selain itu, pengukuran kinerja keuangan juga berguna untuk menetapkan strategi yang tepat agar dapat mencapai tujuan bank (Prasetyo, 2020).

Pengkuran kinerja keuangan bank yang paling dominan digunakan adalah Return on Asset (ROA). Menurut (Dendawijaya, 2001) penilaian ROA lebih dipentingkan daripada ROE oleh Bank Indonesia dalam menentukan kinerja bank. Hal ini dikarenakan Bank Indonesia lebih mengutamakan nilai profitabilitas suatu bank yang diukur dengan asset yang dananya sebagian besar berasal dari dana simpanan masyarakat sehingga ROA lebih mewakili dalam mengukur tingkat profitabilitas perbankan. Berikut perkembangan Return on Asset (ROA) Bank Umum Syariah (BUS) dari tahun 2015 hingga tahun 2020 :

Tabel 1

ROA Bank Umum Syariah (BUS) tahun 2015-2020

\begin{tabular}{cc}
\hline Tahun & ROA \\
\hline 2015 & $0,49 \%$ \\
2016 & $0,63 \%$ \\
2017 & $0,63 \%$ \\
2018 & $1,28 \%$ \\
2019 & $1,73 \%$ \\
2020 & $1,47 \%$ \\
\hline Sumber $:$ SPS Otoritas Jasa Keuangan Tahun 2015-2020
\end{tabular}

Sumber : SPS Otoritas Jasa Keuangan Tahun 2015-2020.

Dari Tabel 1 dapat dilihat bahwa perkembangan Perbankan Syariah untuk saat ini sepertinya hanya sebatas pada bertambahnya jumlah bank syariah saja, tanpa diimbangi dengan perkembangan Return on Assets-nya. Menurut Peraturan Bank Indonesia No. 6/9/PBI/2004 standar minimum ROA yang ditetapkan untuk masing-masing bank adalah 1,5 \%. Jika dilihat pada tabel diatas, ROA Bank Umum Syariah (BUS) dari tahun 2015-2018 masih berada dibawah standar minimum yang telah ditetapkan oleh Bank Indonesia yaitu masih dibawah 1,5\%. Pada tahun 2019, ROA Bank Umum Syariah (BUS) mengalami peningkatan menjadi $1,73 \%$, angka tersebut sudah masuk dalam kategori bank yang sehat. Namun pada tahun 2020 ROA Bank Umum Syariah (BUS) mengalami penurunan kembali menjadi $1,47 \%$ yang artinya ROA Bank Umum Syariah (BUS) kembali berada dibawah 
standar minimum atau kurang sehat. Dengan ROA yang rendah maka hal ini dapat menunjukkan bahwa tingkat keuntungan yang didapat Bank Umum Syariah (BUS) sedang mengalami penurunan yang artinya kinerja keuangan Bank Umum Syariah (BUS) dalam keadaan melemah.

Dilihat dari kondisi di atas, bank syariah dituntut untuk lebih bekerja keras lagi dalam meningkatkan kinerjanya. Untuk meningkatkan kinerja Bank Syariah tersebut maka perlu ada Good Corporate Governance. Perbedaan mendasar dalam perbandingan prinsip Good Corporate Governance pada Bank Syariah dan Bank Konvensional terletak pada prinsip syariah yang digunakan oleh bank syariah (Hasnati, Dewi, \& Utama, 2019). Penerapan Good Corporate Governance pada Bank Syariah harus berdasarkan prinsip syariah (sharia compliance) dan dalam menjalankan kegiatan usahanya Bank Syariah juga tidak lepas dari prinsip syariah. Untuk menjamin terlaksananya prinsip shariah dalam implementasi Good Corporate Governance dan kegiatan operasional Bank Syariah terdapat pihak yang terafiliasi yaitu Dewan Pengawas Syariah (DPS).

Penelitian yang mengaitkan karakteristik Dewan Pengawas Syariah (DPS) dengan kinerja keuangan bank syariah di Indonesia masih sangat terbatas.Dalam pertumbuhan dan perkembangan bank syariah di Indonesia saat ini perlu dikaji hal-hal yang dapat mempengaruhi kinerja bank syariah, seperti Dewan Pengawas Syariah (DPS). Selain itu, dengan melihat adanya inkonsistensi hasil penelitian terdahulu, maka perlu diuji lebih lanjut mengenai pengaruh karakteristik Dewan Pengawas Syariah (DPS) terhadap kinerja keuangan bank syariah di Indonesia. Penelitian ini berbeda dengan penelitian sebelumnya. Penelitian ini hanya fokus pada satu negara yaitu Indonesia yang merupakan negara dengan populasi muslim terbesar di Dunia. Penelitian ini juga menggunakan variabel kontrol yaitu ukuran bank dan umur bank. Berdasarkan penjelasan latar belakang diatas, peneliti tertarik untuk melakukan penelitian tentang pengaruh karakteristik Dewan Pengawas Syariah (DPS) terhadap kinerja keuangan Bank Syariah di Indonesia. Maka penelitian ini mengambil judul "Pengaruh Karakteristik Dewan Pengawas Syariah (DPS) Terhadap Kinerja Keuangan Bank Umum Syariah Di Indonesia Periode 2016-2020"

\section{REVIU LITERATUR DAN HIPOTESIS Resource Dependency Theory (RDT)}

Resource Dependency Theory (RDT) menyatakan bahwa strategi, struktur, dan keberlangsungan hidup perusahaan sangat bergantung pada sumber daya manusia untuk menghubungkan dengan lingkungan eksternal (Aprilia, Febriany, Haryono, \& Marsetio, 2020). Pada bank syariah salah satu sumber daya tersebut adalah Dewan Pengawas Syariah (DPS). Dewan pengawas syariah (DPS) memiliki tugas penting seperti menentukan strategi bank dan menghubungkan bank dengan lingkungan eksternal tempat bank beroperasi (Wang, Chen, Fang, \& Tian, 2018). Dengan demikian, Dewan Pengawas Syariah (DPS) merupakan aset berharga bagi bank syariah yang berkontribusi dalam menjaga keberlangsungan usaha bank syariah (Hillman \& Dalziel, 2003). Dewan Pengawas Syariah (DPS) akan terlibat dalam pengawasan dan memberikan saran dalam membuat keputusan (Hillman \& Dalziel, 2003). Lebih lanjut, untuk meningkatkan hubungan eksternal yang semakin efektif, bank syariah termotivasi untuk untuk menambah jumlah anggota Dewan Pengawas Syariah (DPS) yang lebih banyak (Daromes \& Jao, 2020). Hal ini bermanfaat bagi bank syariah dari sudut pandang ketergantungan sumber daya bahwa para Dewan Pengawas Syariah (DPS) membawa sumber daya berharga untuk bank syariah (Pfeffer \& Salancik, 1978). 


\section{Kinerja Keuangan}

Kinerja (performance) dalam kamus istilah akuntansi adalah kualifikasi dari keefektifan dalam pengoperasian bisnis selama periode tertentu. Kinerja bank secara umum merupakan gambaran prestasi yang dicapai oleh bank dalam operasionalnya. Menurut (Esomar, 2021), kinerja keuangan bank merupakan kemampuan suatu bank untuk melakukan kegiatan operasi perbankan secara normal dan mampu memenuhi semua kewajibannya dengan baik dengan cara-cara yang sesuai dengan peraturan perbankan yang berlaku. Kinerja keuangan berhubungan dengan rasio keuangan. Rasio keuangan digunakan untuk mengukur kinerja keuangan perusahaan apakah perusahaan mengalami peningkatan maupun penurunan kinerja keuangannya (Esomar, 2021).

\section{Pengukuran Kinerja Keuangan}

\section{a. Return on Assets (ROA)}

Rasio Return on Assets (ROA) merupakan pengukuran kinerja keuangan perusahaan yang sering digunakan untuk menilai tingkat efektivitas dari seluruh operasi perusahaan. Return on Assets (ROA) adalah salah satu bentuk dari rasio profitabilitas untuk mengukur kemampuan perusahaan dalam menghasilkan laba dengan menggunakan total biaya yang ada dan setelah biaya-biaya modal (biaya yang digunakan untuk mendanai aktiva) dikeluarkan dari analisis (Ikhwal, 2016). Adapun rumus dari Return on Assets (ROA) adalah sebagai berikut :

$$
\mathrm{ROA}=\underline{\mathrm{EBIT}}(\text { Earning Before Interest and Tax) }
$$

\section{Total Aset}

\section{b. Return on Equity (ROE)}

Return on Equity (ROE) memperlihatkan sejauh mana perusahaan mengelola modal sendiri secara efektif, mengukur tingkat keuntungam dari investasi yang telah dilakukan pemilik modal sendiri atau pemegang saham perusahaan (Winarmo, 2019). Return on Equity (ROE) merupakan rasio yang sering digunakan oleh para pemegang saham untuk melihat dan mengukur tingkat keberhasilan yang dicapai perusahaan. Rasio ini menggunakan hubungan antara keuntungan setelah pajak dengan modal sendiri yang digunakan perusahaan, yang dianggap sebagai modal sendiri adalah saham biasa, agio saham, laba ditahan, saham preferen, dan cadangan-cadangan lain (Ikhwal, 2016). Berikut rumus dari rasio Return on Equity (ROE) :

$\mathrm{ROE}=\underline{\text { Laba bersih setelah bunga dan pajak }}$ Jumlah saham beredar

\section{c. Cost Income Ratio (CIR)}

Cost income ratio (CIR) merupakan rasio yang menunjukkan seberapa besar biaya yang harus dikeluarkan oleh bank dalam memperoleh pendapatan. Setiap kegiatan yang dilakukan bank untuk memperoleh pendapatan maka akan ada pengorbanan yang harus dilakukan dan biaya yang akan dikeluarkan. Biaya adalah salah satu faktor yang ikut menentukan tinggi rendahnya profitabilitas. Rasio ini berguna sebagai pengukur kualitas dari manajemen yang dimiliki oleh bank. Berikut rumus dari Cost income ratio (CIR) :

$\mathrm{CIR}=\underline{\text { Beban usaha/operating expense }}$

Pendapatan usaha/operating revenue

\section{Pengaruh Ukuran DPS terhadap ROA}

Berdasarkan resource dependency theory, dewan pengawas syariah yang berukuran besar lebih baik dibanding dewan pengawas syariah berukuran kecil (Quttainah, Liang, \& Qiang, 2013). Ukuran Dewan Pengawas Syariah (DPS) yang besar dapat mempengaruhi kinerja keuangan bank syariah, karena semakin banyak anggota Dewan Pengawas Syariah (DPS) yang terdiri dari para sarjana dengan memiliki banyak pengalaman dan keterampilan 
serta ilmu pengetahuan mengenai hukum Islam dan fiqh akan berdampak pada interpretasi produk dan operasional bank syariah yang akan menjadi lebih baik sehingga pada akhirnya kinerja bank syariah juga akan meningkat (Hamza, 2016). Ukuran Dewan Pengawas Syariah (DPS) berpengaruh signifikan terhadap kinerja keuangan bank syariah telah dibuktikan dalam penelitian (Matoussi \& Grassa, 2012), (Mollah \& Zaman, 2015), (Nomran, Haron, \& Hassan, 2018), dan (Baklouti, 2020). Berdasarkan uraian di atas dapat dinyatakan hipotesis sebagai berikut:

H1: Ukuran Dewan Pengawas Syariah (DPS) berpengaruh positif terhadap kinerja keuangan Bank Umum Syariah.

\section{Pengaruh Kualifikasi Pendidikan DPS terhadap ROA}

Dewan Pengawas Syariah (DPS) dengan tingkat pendidikan yang tinggi memiliki kemampuan analisis yang lebih kuat dan profesional, dapat memberikan keputusan yang efektif, serta dapat memilih dan menetapkan apakah suatu peraturan dapat dilakukan sesuai prinsip syariah atau tidak (Setiawan, 2020). Kualifikasi pendidikan anggota Dewan Pengawas Syariah (DPS) merupakan hal penting karena dapat menjadi penentu kualitas dari anggota Dewan Pengawas Syariah (DPS) itu sendiri. Resource dependency theory menjelaskan bahwa anggota dewan pengawas syariah yang berkualitas dan berpendidikan tinggi memainkan peran penting dalam meningkatkan daya saing bank (Gabrielsson \& Huse, 2005). Sehinga dapat dikatakan bahwa tingginya tingkat pendidikan dewan pengawas syariah dapat meningkatkan kinerja keuangan bank syariah (Musibah \& Alfattani, 2014). Hal ini seiring dengan hasil penelitian terdahulu seperti (Matoussi \& Grassa, 2012), (Hakimi, Rachdi, Mokni, \& Hssini, 2018), (Nathan, 2010), dan (Nomran, Haron, \& Hassan, 2018) yang menyatakan bahwa anggota dewan pengawas syariah yang berpendidikan tinggi berpengaruh signifikan terhadap kinerja keuangan bank syariah. Berdasarkan uraian di atas dapat dinyatakan hipotesis sebagai berikut:

H2: Kualifikasi pendidikan Dewan Pengawas Syariah (DPS) berpengaruh positif terhadap kinerja keuangan Bank Umum Syariah.

\section{Pengaruh Jumlah Rapat DPS terhadap ROA}

Jika dewan pengawas syariah melakukan rapat dengan waktu yang teratur dan sering maka akan mewujudkan efektivitas dan efisiensi pada dewan pengawas syariah (Ntim, Soobaroyen, \& Broad, 2017). Semakin sering Dewan Pengawas Syariah melakukan rapat maka semakin meningkat pemantauan semua transaksi yang pada gilirannya akan meningkatkan kinerja bank syariah (Baklouti, 2020). Penelitian (Garas, 2012), (Baklouti, 2020), dan (Nathan, 2010) membuktikan bahwa rapat Dewan Pengawas Syariah yang rutin dapat meningkatkan kinerja bank syariah. Berdasarkan uraian di atas dapat dinyatakan hipotesis sebagai berikut:

H3: Jumlah rapat Dewan Pengawas Syariah (DPS) berpengaruh positif terhadap kinerja keuangan Bank Umum Syariah.

\section{Pengaruh Reputasi DPS terhadap ROA}

Berdasarkan resource dependency theory, dewan pengawas syariah merupakan sumber daya penting bagi bank syariah yang dapat meningkatkan kinerja keuangan bank syariah (Pfeffer \& Salancik, 1978). Reputasi baik yang dimiliki dewan pengawas syariah merupakan keuntungan yang didapat bank syariah (Pfeffer \& Salancik, 1978). Dewan pegawas syariah bertugas untuk memastikan kegiatan usaha dan produk bank sesuai dengan prinsip syariah. Jika dewan pengawas syariah memiliki reputasi yang baik, maka nasabah dan deposan bank akan meningkat, sehingga akan mengurangi risiko likuiditas dan meningkatkan kinerja keuangan bank syariah (Farook, Hassan, \& Lanis, 2011); (Nomran, Haron, \& Hassan, 
2018). Penelitian (Nomran, Haron, \& Hassan, 2018), (Nugraheni, 2018) dan (Nugroho, 2020) menemukan bahwa reputasi Dewan Pengawas Syariah (DPS) berpengaruh positif terhadap kinerja keuangan bank syariah. Berdasarkan uraian di atas dapat dinyatakan hipotesis sebagai berikut:

H4: Reputasi Dewan Pengawas Syariah (DPS) berpengaruh positif terhadap kinerja keuangan Bank Umum Syariah.

\section{METODE PENELITIAN}

Jenis penelitian ini adalah penelitian kuantitatif dan termasuk studi kausal yang bertujuan untuk menguji apakah satu variabel dapat menyebabkan variabel yang lain berubah atau tidak. Populasi dalam penelitian ini meliputi Bank Umum Syariah (BUS) yang terdaftar di Otoritas Jasa Keuangan (OJK) dari tahun 2016 hingga tahun 2020. Pemilihan sampel dalam penelitian ini menggunakan metode purposive sampling, yaitu teknik pengambilan sampel dengan mempertimbangkan kriteria tertentu.

Urutan kriteria sampel dalam penelitian ini adalah : (1) Bank Umum Syariah (BUS) yang terdapat di Indonesia pada periode penelitian 2016-2020 yang terdaftar di Otoritas Jasa Keuangan (OJK), (2) Bank Umum Syariah (BUS) yang menerbitkan laporan tahunan lengkap dan laporan good corporate governance pada periode penelitian 2016-2020, (3) Bank Umum Syariah (BUS) yang mempunyai data lengkap mengenai kinerja keuangan dan Dewan Pengawas Syariah pada Laporan keuangan dan laporan good corporate governance selama tahun 2016-2020. Sampel dalam penelitian ini meliputi 13 Bank Umum Syariah (BUS) yang terdaftar di Otoritas Jasa Keuangan (OJK) dari tahun 2016 hingga tahun 2020. Jenis data yang digunakan dalam penelitian ini adalah data sekunder. Data sekunder dalam penelitian ini terdiri dari data mengenai ukuran Dewan Pengawas Syariah (DPS), kualifikasi pendidikan Dewan Pengawas Syariah (DPS), jumlah rapat Dewan Pengawas Syariah (DPS), reputasi Dewan Pengawas Syariah (DPS), serta kinerja keuangan pada laporan keuangan tahunan dan laporan GCG Bank Umum Syariah periode 2016-2020. Data laporan keuangan tahunan dan laporan GCG tersebut diperoleh dari website masing-masing bank. Teknik pengumpulan data yang digunakan dalam penelitian ini adalah teknik dokumentasi.

Teknik analisis data pada penelitian ini adalah menggunakan analisis regresi linear berganda. Pengolahan data dilakukan dengan menggunakan software SPSS. Adapun tahaptahap pengujian dalam penelitian ini adalah : (1) analisis statistik deskriptif, (2) Pengujian asumsi klasik yang terdiri dari uji normalitas, uji multikolonieritas, uji heteroskedastisitas, dan uji autokorelasi, (3) analisis koefisien determinasi $\left(\mathrm{R}^{2}\right)$, (3) Uji F, dan (4) Uji t. Adapun model regresi yang digunakan adalah sebagai berikut :

$$
\mathrm{Y}=\mathrm{a}+\beta_{1} \mathrm{X}_{1}+\beta_{2} \mathrm{X}_{2}+\beta_{3} \mathrm{X}_{3}+\beta_{4} \mathrm{X}_{4}+\mathrm{e}
$$

Penelitian ini menggunakan variabel kontrol sebagai perbandingan, maka disusun rumus yang dapat digunakan yaitu sebagai berikut :

$$
\mathrm{Y}=\mathrm{a}+\beta_{1} \mathrm{X}_{1}+\beta_{2} \mathrm{X}_{2}+\beta_{3} \mathrm{X}_{3}+\beta_{4} \mathrm{X}_{4}+\beta_{3} \mathrm{X}_{5}+\beta_{4} \mathrm{X}_{6}+\mathrm{e}
$$

$$
\begin{aligned}
& \text { Keterangan : } \\
& \mathrm{Y}=\text { kinerja keuangan } \\
& \mathrm{a}=\text { Konstanta } \\
& \beta=\text { Koefisien Regresi } \\
& \mathrm{X}_{1}=\text { Ukuran Dewan Pengawas Syariah (DPS) } \\
& \mathrm{X}_{2}=\text { Kualifikasi pendidikan Dewan Pengawas Syariah (DPS) }
\end{aligned}
$$


$\mathrm{X}_{3}=$ Jumlah rapat Dewan Pengawas Syariah (DPS)

$\mathrm{X}_{4}=$ Reputasi Dewan Pengawas Syariah (DPS)

$\mathrm{X}_{5}=$ Ukuran bank

$\mathrm{X}_{6}=$ Umur bank

$\mathrm{e}=$ Prediction Error

\section{HASIL PENELITIAN}

Analisis Statistik Deskriptif

Statistik deskriptif memberikan gambaran atau deskripsi suatu data yang dlihat dari nilai rata-rata (mean), standar deviasi, varian, maksimum, dan minimum (Ghozali, 2013). Berikut hasil analisis statistik deskriptif, sebagai berikut :

Tabel 2

Uji Statistik Deskriptif

\begin{tabular}{lrrrrr}
\hline & N & \multicolumn{1}{c}{ Minimum } & \multicolumn{1}{c}{ Maximum } & \multicolumn{1}{c}{ Mean } & Std. Deviation \\
\hline SIZE & 65 & 2 & 3 & 2.23 & .425 \\
EDU & 65 & 50 & 100 & 92.12 & 14.638 \\
MEET & 65 & 7 & 48 & 15.09 & 7.182 \\
REP & 65 & 50 & 100 & 91.55 & 18.170 \\
ROA & 65 & .00 & 71.60 & 3.4372 & 9.21539 \\
Valid N (listwise) & 65 & & & & \\
\hline
\end{tabular}

Berdasarkan Tabel 2 dapat dijelaskan bahwa ukuran DPS memiliki nilai maximum sebesar 3 dan nilai minimum sebesar 2 dengan nilai mean 2,23. Nilai standar deviasi ukuran DPS sebesar 0,425. Kualifikasi pendidikan DPS memiliki nilai maximum sebesar 100 dan nilai minimum sebesar 50 dengan nilai mean 92,12. Nilai standar deviasi kualifikasi pendidikan DPS sebesar 14,638. Jumlah rapat DPS memiliki nilai maximum sebesar 48 dan nilai minimum sebesar 7 dengan nilai mean 15,09. Nilai standar deviasi jumlah rapat DPS sebesar 7,182. Reputasi DPS memiliki nilai maximum sebesar 100 dan nilai minimum sebesar 50 dengan nilai mean 91,55. Nilai standar deviasi reputasi DPS sebesar 18,170. ROA memiliki nilai maximum sebesar 71,6 dan nilai minimum sebesar 0 dengan nilai mean 3,4372. Nilai standar deviasi ukuran DPS sebesar 9,21539. Nilai mean lebih besar dari nilai standar deviasi menunjukkan bahwa penyimpangan data yang terjadi rendah sehingga penyebaran nilainya merata.

\section{Uji Asumsi Klasik}

\section{Uji Normalitas}

Uji normalitas bertujuan untuk menguji apakah dalam model regresi, variabel pengganggu atau residual mempunyai distribusi normal (Janie, 2012). Berikut tabel hasil uji normalitas sebagai berikut :

Tabel 3

Uji Normalitas

\section{One-Sample Kolmogorov-Smirnov Test}

\begin{tabular}{llr} 
& & Unstandardized Residual \\
\hline $\mathrm{N}$ & & 65 \\
Normal Parameters $^{\mathrm{a}}$ & Mean & .0000000 \\
& Std. Deviation & .94000687 \\
Most Extreme Differences & Absolute & .167 \\
& Positive & .167 \\
& Negative & -.088
\end{tabular}


Sumber : data diolah dengan SPSS

Berdasarkan tabel diatas, dapat dilihat bahwa data berdistribusi normal. Hal ini ditunjukan dengan nilai Asymp. Sig. (2-tailed) yang lebih besar dari 0,05 yaitu sebesar 0,054. Hal ini berarti data residualnya terdistribusi normal, karena nilai signifikannya lebih besar dari 0,05 .

\section{Uji Multikolonieritas}

Uji multikolonieritas bertujuan untuk menguji apakah dalam model regresi ditemukan adanya korelasi yang tinggi atau sempurna antar variabel independen (Janie, 2012). Berikut tabel hasil uji multikolonieritas sebagai berikut :

Tabel 4

Uji Multikolonieritas

\begin{tabular}{|c|c|c|c|c|c|c|c|c|}
\hline \multirow[b]{2}{*}{ Model } & & \multicolumn{2}{|c|}{$\begin{array}{l}\text { Unstandardized } \\
\text { Coefficients }\end{array}$} & \multirow{2}{*}{$\begin{array}{c}\text { Standardized } \\
\text { Coefficients } \\
\text { Beta } \\
\end{array}$} & \multirow[b]{2}{*}{$\mathrm{t}$} & \multirow[b]{2}{*}{ Sig. } & \multicolumn{2}{|c|}{$\begin{array}{l}\text { Collinearity } \\
\text { Statistics }\end{array}$} \\
\hline & & $\mathrm{B}$ & Std. Error & & & & Tolerance & VIF \\
\hline \multirow[t]{5}{*}{1} & (Constant) & -.331 & 5.601 & & -.059 & .953 & & \\
\hline & SIZE & -.532 & 1.069 & -.072 & -.498 & .620 & .764 & 1.309 \\
\hline & EDU & .041 & .033 & .189 & 1.241 & .220 & .684 & 1.463 \\
\hline & MEET & -.042 & .060 & -.095 & -.701 & .486 & .857 & 1.167 \\
\hline & REP & .004 & .024 & .024 & .179 & .859 & .853 & 1.172 \\
\hline
\end{tabular}

Sumber : data diolah dengan SPSS.

Berdasarkan tabel diatas dapat dilihat bahwa nilai VIF dan tolerance dari masingmasing variabel menunjukkan bahwa tidak terdapat gejala multikolonieritas. Hal ini dibuktikan dengan tidak adanya nilai VIF yang diatas 10 dan tidak adanya nilai tolerance yang dibawah 0,10 . Variabel SIZE menunjukkan nilai tolerance sebesar 0,764 dan nilai VIF sebesar 1,309. Variabel EDU menunjukkan nilai tolerance sebesar 0,684 dan nilai VIF sebesar 1,463. Variabel MEET menunjukkan nilai tolerance sebesar 0,857 dan nilai VIF sebesar 1,167. Variabel REP menunjukkan nilai tolerance sebesar 0,853 dan nilai VIF sebesar 1,172 .

\section{Uji Autokorelasi}

Uji autokorelasi adalah pengujian yang bertujuan untuk melihat apakah model regresi linear terdapat korelasi antar data sebelum dengan data sesudahnya dalam data yang disusun berdasarkan waktu (time series).

\section{Tabel 5}

\section{Uji Autokorelasi}

\begin{tabular}{lrrrrr}
\hline Model & R & R Square & Adjusted R Square & Std. Error of the Estimate & Durbin-Watson \\
\hline 1 & $.690^{\mathrm{a}}$ & .476 & .441 & .73802 & 2.102
\end{tabular}

a. Predictors: (Constant), Lag_X4, Lag_X1, Lag_X3, Lag_X2

Sumber : data diolah dengan SPSS

Berdasarkan tabel uji autokerelasi diatas, dapat dilihat bahwa nilai DW sebesar 2,102. Menurut tabel Durbin Watson, dengan jumlah sampel $\mathrm{N}=65$ dan jumlah variabel independen $4(\mathrm{~K}=4)$ maka diperoleh nilai DL 1,4709 dan DU 1,7311. Nilai DW 2,102 lebih besar dari 
batas atas DU yakni 1,7311 dan kurang dari (4-du) yakni 2,2689 sehingga dapat disimpulkan bahwa tidak terjadi autokorelasi.

\section{Uji Heteroskedastisitas}

Uji heteroskedastisitas bertujuan untuk menguji apakah dalam model regresi terjadi ketidaksamaan variance dari residual satu pengamatan ke pengamatan lain (Ghozali, 2013).

Tabel 6

Uji Heteroskedstisitas

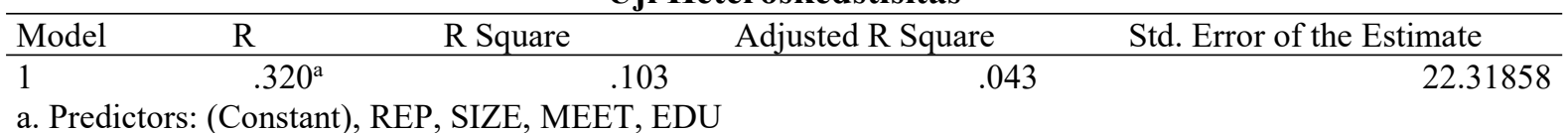

Sumber : data diolah dengan SPSS.

Berdasarkan tabel diatas dapat diketahui bahwa nilai R Square sebesar 0,103. Dengan mengetahui nilai R Square sebesar 0,103, maka dapat diketahui besar nilai Chi Square yaitu, 65 x 0,103 $=6,695$. Sedangkan, besarnya Chi Square tabel adalah sebesar 9,488. Nilai Chi Square hitung $<$ Chi Square tabel, maka tidak terdapat gejala heteroskedastisitas.

Uji F

Penelitian ini menggunakan uji $\mathrm{f}$ bertujuan untuk melihat pengaruh variabel independen secara bersama-sama terhadap variabel dependen.

Tabel 7

Hasil Regresi

\begin{tabular}{|c|c|c|c|c|c|c|}
\hline \multirow{2}{*}{\multicolumn{2}{|c|}{ Model }} & \multicolumn{2}{|c|}{ Unstandardized Coefficients } & \multirow{2}{*}{$\begin{array}{c}\text { Standardized Coefficients } \\
\text { Beta }\end{array}$} & \multirow{2}{*}{$\mathrm{t}$} & \multirow{2}{*}{ Sig. } \\
\hline & & B & Std. Error & & & \\
\hline 1 & (Constant) & -10.159 & 3.238 & & -3.137 & .003 \\
\hline & SIZE & -.990 & .486 & -.224 & -2.039 & .046 \\
\hline & EDU & .059 & .015 & .458 & 3.851 & .000 \\
\hline & MEET & -.004 & .028 & -.017 & -.159 & .874 \\
\hline & REP & -.009 & .012 & -.086 & -.804 & .425 \\
\hline & BSIZE & 1.260 & .289 & .449 & 4.360 & .000 \\
\hline & BAGE & 1.040 & .402 & .267 & 2.590 & .012 \\
\hline
\end{tabular}

Sumber :data diolah dengan SPSS

Dari tabel ANOVA atau uji $\mathrm{F}$ diatas dapat dilihat bahwa nilai signifikansi untuk pengaruh ukuran DPS, kualifikasi pendidikan DPS, jumlah rapat DPS, reputasi DPS, ukuran bank dan umur bank secara simultan terhadap ROA adalah sebesar 0,000 $<0,05$ dan nilai $\mathrm{F}$ hitung $8,748>\mathrm{F}$ tabel 2,25, sehingga dapat disimpulkan bahwa terdapat pengaruh secara simultan ukuran DPS, kualifikasi pendidikan DPS, jumlah rapat DPS, reputasi DPS, ukuran bank dan umur bank terhadap ROA.

\section{Uji Koefisien Determinasi}

Analisis koefisien determinasi bertujuan untuk mengukur seberapa jauh kemampuan model dalam menerangkan variasi variabel dependen (Ghozali, 2013). 
Tabel 8

Koefisien Determinasi

\begin{tabular}{lrrrr}
\hline Model & R & R Square & Adjusted R Square & Std. Error of the Estimate \\
\hline 1 & $.692^{\mathrm{a}}$ & .479 & .425 & 1.43157 \\
\hline Sumber : data diolah dengan SPSS & &
\end{tabular}

Berdasarkan tabel diatas dapat dilihat bahwa besarnya Adjusted R Square adalah 0,425, hal ini berarti 42,5\% variabel dependen ROA dapat dijelaskan dari keempat variabel independen yaitu ukuran DPS, kualifikasi pendidikan DPS, jumlah rapat DPS, reputasi DPS, ukuran bank dan umur bank. Sedangkan sisanya $(100 \%-42,5 \%=57,5 \%)$ dijelaskan oleh variabel-variabel lain yang tidak dijelaskan dalam penelitian ini.

\section{Uji Hipotesis (Uji t)}

Penelitian ini menggunakan uji $\mathrm{t}$ dengan alasan untuk melihat pengaruh satu variabel independen terhadap variabel dependen. Berdasarkan Tabel 7dapat dilihat bahwa nilai Sig. untuk pengaruh ukuran Dewan Pengawas Syariah (DPS) terhadap ROA adalah sebesar 0,046 $<0,05$ dan nilai $t$ hitung $-2,039>\mathrm{t}$ tabel $-2,00172$, sehingga dapat disimpulkan bahwa $\mathrm{H} 1$ diterima yang berarti terdapat pengaruh negatif signifikan ukuran Dewan Pengawas Syariah (DPS) terhadap ROA. Nilai Sig. untuk pengaruh kualifikasi pendidikan Dewan Pengawas Syariah (DPS) terhadap ROA adalah sebesar 0,000 $<0,05$ dan nilai $\mathrm{t}$ hitung 3,851 $>\mathrm{t}$ tabel 2,00172, sehingga dapat disimpulkan bahwa $\mathrm{H} 2$ diterima yang berarti terdapat pengaruh positif signifikan kualifikasi pendidikan Dewan Pengawas Syariah (DPS) terhadap ROA. Nilai Sig. untuk pengaruh jumlah rapat Dewan Pengawas Syariah (DPS) terhadap ROA adalah sebesar $0,874>0,05$ dan nilai t hitung $-0,159<\mathrm{t}$ tabel 2,00172, sehingga dapat disimpulkan bahwa $\mathrm{H} 3$ ditolak yang berarti tidak terdapat pengaruh signifikan jumlah rapat Dewan Pengawas Syariah (DPS) terhadap ROA. nilai Sig. untuk pengaruh jumlah rapat Dewan Pengawas Syariah (DPS) terhadap ROA adalah sebesar 0,425 $>0,05$ dan nilai t hitung $-0,804<\mathrm{t}$ tabel 2,00172, sehingga dapat disimpulkan bahwa $\mathrm{H} 4$ ditolak yang berarti tidak terdapat pengaruh signifikan jumlah rapat Dewan Pengawas Syariah (DPS) terhadap ROA. Nilai Sig. untuk pengaruh ukuran bank terhadap ROA adalah sebesar $0,000<0,05$ dan nilai $t$ hitung 4,360 > t tabel 2,00172, sehingga dapat disimpulkan bahwa H5 diterima yang berarti terdapat pengaruh positif signifikan ukuran bank terhadap ROA. Nilai Sig. untuk pengaruh ukuran bank terhadap ROA adalah sebesar 0,012 <0,05 dan nilai $\mathrm{t}$ hitung 2,590 $>\mathrm{t}$ tabel 2,00172, sehingga dapat disimpulkan bahwa H6 diterima yang berarti terdapat pengaruh positif signifikan umur bank terhadap ROA.

\section{Robustness Check}

Penelitian ini menggunakan alat analisis tambahan yaitu Robustness Check (uji robust). Uji robust digunakan untuk menguji ketahanan atau kevalidan dari hasil penelitian dengan menggunakan model utama (Simangunsong \& Yuyeta, 2015). Uji Robust juga digunakan untuk memvalidasi hasil penelitia (Adisurya, Murhadi, \& Herlambang, 2018). Banyak cara yang dapat digunakan untuk melihat kevalidan dan menguatkan hasil penelitian. Uji Robust dalam penelitian ini dilakukan dengan mengganti proksi variabel dependen yaitu pengukuran kinerja keuangan dengan menggunakan pengukuran ROA kemudian menggantinya dengan pengukuran ROE dan CIR, sehingga dapat dilihat apakah pengaruh variabel independen terhadap variabel dependen tetap konsisten ketika dihitung dengan menggunakan pendekatan yang berbeda. Uji Robust dilakukan dengan cara melakukan seluruh pengujian regresi, uji t, uji f, dan koefisien determinasi. Hasil dari uji robust akan 
dikatakan konsisten jika sesuai dengan hasil uji pada model utama (Adisurya, Murhadi, \& Herlambang, 2018) . Berikut uji robust yang akan dilakukan peneliti yaitu :

Tabel 9

Robustness Check-ROE

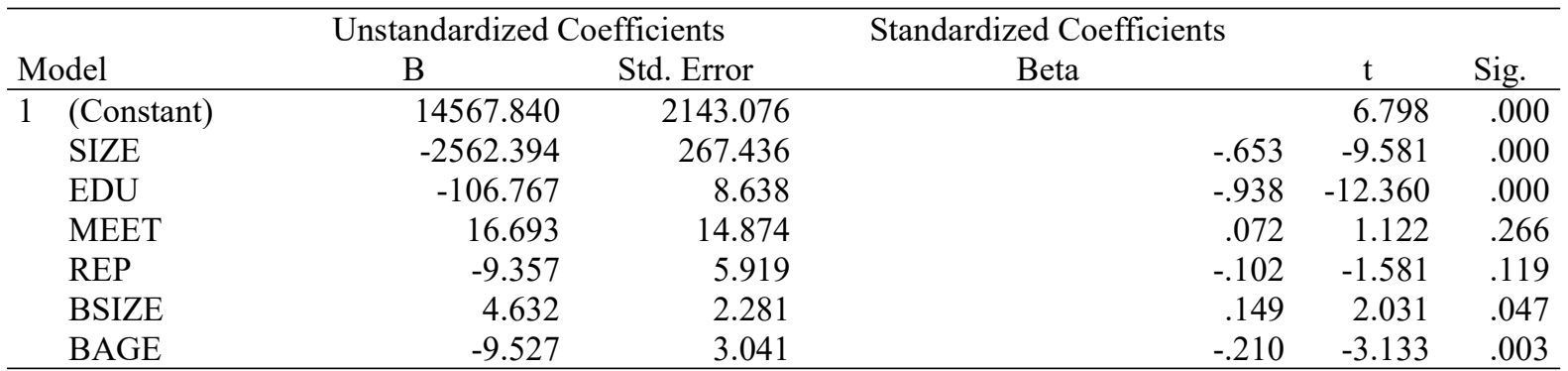

Sumber : data diolah dengan SPSS.

Tabel 10

Robustness Check-CIR

\begin{tabular}{|c|c|c|c|c|c|}
\hline \multirow[b]{2}{*}{ Model } & \multicolumn{2}{|c|}{ Unstandardized Coefficients } & \multicolumn{3}{|l|}{ Standardized Coefficients } \\
\hline & B & Std. Error & Beta & $\mathrm{t}$ & Sig. \\
\hline 1 (Constant) & 4.088 & 29.889 & & .137 & .892 \\
\hline SIZE & 9.361 & 3.730 & .268 & 2.510 & .015 \\
\hline EDU & -.101 & .120 & -.099 & -.836 & .406 \\
\hline MEET & .270 & 207 & .131 & 1.303 & 198 \\
\hline REP & -.094 & .083 & -.114 & -1.133 & 262 \\
\hline BSIZE & .061 & .032 & .221 & 1.924 & .059 \\
\hline BAGE & -.276 & .042 & -.683 & -6.505 & .000 \\
\hline
\end{tabular}

Sumber : data dolah dengan SPSS.

\section{PEMBAHASAN}

\section{Pengaruh Ukuran DPS terhadap ROA}

Variabel ukuran Dewan Pengawas Syariah (DPS) berpengaruh negatif signifikan terhadap kinerja keuangan (ROA) Bank Umum Syariah (BUS) tahun 2016-2020. Sehingga dapat disimpulkan bahwa semakin besar ukuran Dewan Pengawas Syariah (DPS) di suatu bank syariah maka ROA Bank Umum Syariah akan menurun. Hal ini sejalan dengan teori agensi yang menjelaskan bahwa ukuran Dewan Pengawas Syariah (DPS) yang kecil lebih baik dibandingkan ukuran Dewan Pengawas Syariah (DPS) yang besar. Semakin besar ukuran Dewan Pengawas Syariah (DPS) di suatu bank maka akan meningkatkan biaya agensi dan mengurangi profitabilitas bank.

\section{Pengaruh Kualifikasi Pendidikan DPS terhadap ROA}

Variabel kualifikasi pendidikan Dewan Pengawas Syariah (DPS) berpengaruh positif signifikan terhadap kinerja keuangan (ROA) Bank Umum Syariah (BUS) tahun 2016-2020. Resource dependency theory menjelaskan bahwa anggota dewan pengawas syariah yang berkualitas dan berpendidikan tinggi memainkan peran penting dalam meningkatkan daya saing bank (Gabrielsson \& Huse, 2005). Dewan Pengawas Syariah (DPS) dengan tingkat pendidikan yang tinggi memiliki kemampuan analisis yang lebih kuat dan profesional, dapat memberikan keputusan yang efektif, serta dapat memilih dan menetapkan apakah suatu peraturan dapat dilakukan sesuai prinsip syariah atau tidak (Setiawan, 2020). Sehinga dapat dikatakan bahwa tingginya tingkat pendidikan dewan pengawas syariah dapat meningkatkan kinerja keuangan bank syariah (Musibah \& Alfattani, 2014). 


\section{Pengaruh Jumlah Rapat DPS terhadap ROA}

Variabel jumlah rapat Dewan Pengawas Syariah (DPS) tidak berpengaruh signifikan terhadap kinerja keuangan Bank Umum Syariah (BUS) tahun 2016-2020. Menurut Peraturan Bank Indonesia No. 11/33/PBI/2009 tentang pelaksanaan good corporate governance untuk Bank Umum Syariah menjelaskan bahwa Dewan Pengawas Syariah wajib menyelenggarakan rapat Dewan Pengawas Syariah paling kurang 1 (satu) kali dalam 1 (satu) bulan (Nugraheni, 2018). Berdasarkan data dari laporan tahunan dan laporan GCG, terlihat bahwa Bank Umum Syariah di Indonesia pada tahun 2016 hingga 2020 telah melaksanakan rapat sesuai peraturan yang telah ditetapkan BI dan OJK yaitu 12 kali dan bahkan ada yang lebih dari 12 kali dalam setahun. Namun, tidak semua rapat tersebut dihadiri oleh seluruh anggota Dewan Pengawas Syariah. Bank Umum Syariah tidak menjelaskan alasan kenapa Dewan Pengawas Syariah tidak dapat menghadiri rapat tersebut. Sehingga, hal ini dapat mempengaruhi kualitas dari rapat Dewan Pengawas Syariah. Kualitas keputusan oleh anggota Dewan Pengawas Syariah mungkin rendah ketika mereka tidak hadir dalam rapat tersebut (Muneeza dan Hassan, 2014).

\section{Pengaruh Reputasi DPS terhadap ROA}

Variabel reputasi Dewan Pengawas Syariah (DPS) tidak berpengaruh signifikan terhadap kinerja keuangan Bank Umum Syariah (BUS) tahun 2016-2020. Memilih anggota dewan pengawas syariah yang bereputasi baik diharapkan dapat meningkatkan kinerja bank syariah. Dalam penelitian ini, reputasi Dewan Pengawas Syariah (DPS) diukur dengan persentase anggota Dewan Pengawas Syariah (DPS) yang duduk di DSN-MUI atau setidaknya memiliki satu keanggotaan Dewan Pengawas Syariah di Lembaga Syariah lain pada saat yang sama (Rahman \& Bukair, 2013). Namun, Berdasarkan data dari laporan tahunan dan laporan GCG, terlihat bahwa aggota Dewan Pengawas Syariah (DPS) hanya sedikit yang duduk di DSN-MUI, dan lebih banyak memiliki keanggotaan Dewan Pengawas Syariah di Lembaga Syariah lain. Sehingga, hal ini bisa saja menjadi penyebab reputasi Dewan Pengawas Syariah (DPS) tidak dapat meningkatkan atau mempengaruhi ROA Bank Umum Syariah (BUS).

\section{Pengaruh Ukuran Bank terhadap ROA}

Variabel ukuran bank berpengaruh signifikan terhadap kinerja keuangan Bank Umum Syariah (BUS) tahun 2016-2020. Bank dengan skala atau ukuran yang lebih besar lebih mudah untuk mendapatkan sumber dana dari pihak eksternal bank dan mengakses pasar (Novyanny \& Turagan, 2013). Bank yang berukuran besar juga memiliki akses yang banyak untuk membeli aset, mendapatkan pinjaman, melakukan investasi dan lain sebagainya.Sehingga, hal ini dapat meningkatkan kinerja bank.

\section{Pengaruh Umur Bank terhadap ROA}

Variabel umur bank berpengaruh signifikan terhadap kinerja keuangan Bank Umum Syariah (BUS) tahun 2016-2020. Bank yang telah lama berdiri atau dapat dikatakan lebih tua pasti memiliki lebih banyak pegalaman sehingga akan lebih mengetahui langkah apa yang harus diambil ketika mengalami suatu masalah (Novyanny \& Turagan, 2013). Bank yang telah lama berdiri lebih dikenal oleh masyarakat dibandingkan bank yang baru berdiri. Sehingga, masyarakat lebih percaya untuk menggunakan produk dan jasa bank yang telah lama berdiri.

\section{Robustness Check}

Hasil uji robust ini dapat memberikan tambahan pengetahuan baru khususnya untuk pengaruh karakteristik Dewan Pengawas Syariah terhadap kinerja keuangan bahwa dari hasil 
uji robustness yang menunjukkan bahwa ROE dan CIR yang merupakan proksi pengukuran kinerja keuangan memberikan hasil yang konsisten dan dapat saling melengkapi.

\section{KESIMPULAN, KETERBATASAN DAN SARAN Kesimpulan}

Penelitian ini bertujuan untuk menguji pengaruh ukuran DPS, kualifikasi pendidikan DPS, jumlah rapat DPS, dan reputasi DPS terhadap kinerja keuangan Bank Umum Syariah (BUS) yang terdaftar di OJK tahun 2016-2020. Berdasarkan hasil penelitian yang telah dilakukan mulai dai tahap pengumpulan data, pengolahan data dan analisis data, maka dapat ditarik kesimpulan sebagai berikut : ukuran Dewan Pengawas Syariah (DPS) berpengaruh negatif signifikan terhadap kinerja keuangan (ROA) Bank Umum Syariah (BUS) tahun 20162020, kualifikasi pendidikan Dewan Pengawas Syariah (DPS) berpengaruh positif signifikan terhadap kinerja keuangan (ROA) Bank Umum Syariah (BUS) tahun 2016-2020, jumlah rapat Dewan Pengawas Syariah (DPS) tidak berpengaruh signifikan terhadap kinerja keuangan Bank Umum Syariah (BUS) tahun 2016-2020, dan reputasi Dewan Pengawas Syariah (DPS) tidak berpengaruh signifikan terhadap kinerja keuangan Bank Umum Syariah (BUS) tahun 2016-2020.

\section{Keterbatasan}

Penelitian ini hanya berfokus pada Bank Umum Syariah (BUS), tanpa memasukkan Unit Usaha Syariah (UUS) dan Bank Pembiayaan Rakyat Syariah (BPRS). Karakteristik Dewan Pengawas Syariah hanya terbatas pada empat karakteristik saja, yaitu ukuran Dewan Pengawas Syariah, kualifikasi pendidikan Dewan Pengawas Syariah, jumlah rapat Dewan Pengawas Syariah dan reputasi Dewan Pengawas Syariah.

\section{Saran}

Bagi peneliti selanjutnya dapat menggunakan sampel selain Bank Umum Syariah (BUS), yaitu dengan memasukkan Unit Usaha Syariah (UUS) dan Bank Pembiayaan Rakyat Syariah (BPRS). Peneliti selanjutnya juga bisa menambah karakteristik Dewan Pengawas Syariah yang lain, seperti kehadiran wanita dalam Dewan Pengawas Syariah, evaluasi masing-masing anggota Dewan Pengawas Syariah, perubahan komposisi Dewan Pengawas Syariah, dan jumlah hari pengawasan Dewan Pengawas Syariah.

\section{DAFTAR PUSTAKA}

Adisurya, D., Murhadi, W. R., \& Herlambang, A. (2018). Pengaruh Karakteristik Badan Usaha dan Struktur Modal Terhadap Performa Perusahaan di Sektor Agriculture yang Terdaftar di Bursa Efek ASEAN Periode 2011-2015. Calyptra.

Aprilia, A. W., Febriany, R., Haryono, L., \& Marsetio, N. C. (2020). Pengaruh Karakteristik Direksi Terhadap Kinerja Perusahaan yang Terdaftar di Bursa Efek Indonesia. Jurnal Akuntansi.

Baklouti, I. (2020). Is the Sharia Supervisory Board A Friend Or An Enemy Of Islamic Banks? Journal of Islamic Marketing.

Daromes, F. E., \& Jao, R. (2020). Peran Mediasi Kinerja Keuangan Pada Hubungan Dewan Direksi Dengan Reaksi Investor. Jurnal Akuntansi.

Dendawijaya, L. (2001). manajemen perkreditan. jakarta: ghalia indonesia.

Esomar, M. J. (2021). Analisa Perbedaan Kinerja Keuangan Bank Syariah dan Bank Umum Swasta Nasional. Jurnal Manajemen, Ekonomi, Keuangan, dan Akuntansi. 
Fajriyah, Y., \& Jumady, E. (2021). Pembiayaan Bagi Hasil Dan Financing To Deposit Ratio Terhadap Profitabilitas Bank Umum Syariah Di Indonesia. Islamic Banking : Jurnal Pemikiran dan pengembangan perbankan syariah.

Farook, S., Hassan, K., \& Lanis, R. (2011). Determinants Of Corporate Social Responsibility Disclosure: The Case Of Islamic Banks. Journal of Islamic Accounting and Business Research.

Gabrielsson, J., \& Huse, M. (2005). Outside Directors In SME Boards: A Call For Theoretical Reflections. Corporate Board: role, duties and composition.

Garas, S. N. (2012). The Conflicts Of Interest Inside The Shari'a Supervisory Board. International Journal of Islamic and Middle Eastern Finance and Management.

Ghozali, I. (2013). Aplikasi Analisis Multivariate dengan Program IBM SPSS 21 Update PLS Regresi. Semarang: Badan Penerbit Universitas Diponegoro.

Hakimi, A., Rachdi, H., Mokni, R. B., \& Hssini, H. (2018). Do Board Characteristics Affect Bank Performance? Evidence From The Bahrain Islamic Banks. Journal of Islamic Accounting and Business Researc.

Hamza, H. (2016). Does Investment Deposit Return In Islamic Banks Reflect PLS Principle? Borsa Istanbul Review.

Hasan, Z. (2009). Corporate Governance: Western And Islamic Perspectives. International Review of Business Research Papers.

Hasnati, Dewi, S., \& Utama, A. S. (2019). Perbandingan Prinsip Good Corporate Governance pada Bank Konvensional dan Bank Syariah dalam Sistem Hukum di Indonesia. Mizan: Journal of Islamic Law.

Hillman, A. J., \& Dalziel, T. (2003). Boards Of Directors And Firm Performance: Integrating Agency And Resource Dependence Perspectives. Academy of Management review.

Ikhwal, N. (2016). Analisis ROA dan ROE Terhadap Profitabilitas Bank Di Bursa Efek Indonesia. Al-Masraf: Jurnal Lembaga Keuangan dan Perbankan.

Janie, D. N. (2012). Statistik Deskriptif \& Regresi Linier Berganda Dengan SPSS. Semarang: Semarang University Press.

Matoussi, H., \& Grassa, R. (2012). Is Corporate Governance Different For Islamic Banks? A Comparative Analysis Between The Gulf Cooperation Council Context And The Southeast Asia Contex. The Economic Research Forum.

Mollah, S., \& Zaman, M. (2015). Shari'ah Supervision, Corporate Governance And Performance: Conventional Vs. Islamic Banks. Journal of Banking \& Finance.

Musibah, A. S., \& Alfattani. (2014). The Mediating Effect Of Financial Performance On The Relationship Between Shariah Supervisory Board Effectiveness, Intellectual Capital And Corporate Social Responsibility, Of Islamic Banks In Gulf Cooperation Council Countries. Asian Social Science.

Nathan, S. (2010). The Performance Of Shari'ah Supervisory Boards Within Islamic Financial Institutions In The Gulf Cooperation Council Countries. Corporate Ownership and Control.

Nomran, N. M., Haron, R., \& Hassan, R. (2018). Shari'ah Supervisory Board Characteristics Effects On Islamic Banks' Performance: Evidence from Malaysia. International Journal of Bank Marketing.

Novyanny, M. C., \& Turagan, J. A. (2013). Pengaruh Likuiditas, Ukuran Perusahaan, Umur Perusahaan dan Pertumbuhan Perusahaan Terhadap Profitabilitas Pada Perusahaan Jasa Sektor Perdagangan, Jasa \& Investasi Yang Terdaftar Pada Bursa Efek Indonesia. Jurnal Manajerial Dan Kewirausahaan.

Ntim, C. G., Soobaroyen, T., \& Broad, M. J. (2017). Governance Structures, Voluntary Disclosures And Public Accountability: The Case Of UK Higher Education Institutions. Accounting, auditing \& accountability journal. 
Nugraheni, P. (2018). Sharia Supervisory Board And Social Performance Of Indonesian Islamic Banks. Jurnal Akuntansi dan Auditing Indonesia.

Nugroho, A. (2020). Studi Efektivitas Dewan Pengawas Syariah Terhadap Profitabilitas Dan Resiko Pembiayaan Perbankan Syariah. Proceeding of National Conference on Accounting \& Finance.

Pfeffer, J., \& Salancik, G. R. (1978). The External Control Of Organizations: A Resource Dependence Perspective. New York: Harper \& Row.

Prasetyo, I. (2020). Analisis Kinerja Keuangan Bank Syariah Dan Bank Konvensional Di Indonesia. Jurnal aplikasi manajemen.

Putri, Y. F., Fadah, I., \& Endhiarto, T. (2010). Analisis Perbandingan Kinerja Keuangan Bank Konvensional Dan Bank Syariah. Jurnal Ekonomi Akuntansi dan Manajemen.

Quttainah, M. A., Liang, S., \& Qiang, W. (2013). Do Islamic Banks Employ Less Earnings Management? Journal of International Financial Management \& Accountin.

Rahman, A. A., \& Bukair, A. A. (2013). The Influence Of The Shariah Supervision Board On Corporate Social Responsibility Disclosure By Islamic Banks Of Gulf Co-Operation Council Countries. Asian Journal of Business and Accounting.

Setiawan, F. (2020). Pengaruh Karakteristik Dewan Pengawas Syari'ah dan Ukuran Dewan Komisaris terhadap Pengungkapan Islamic Social Reporting. Al Maal: Journal of Islamic Economics and Banking.

Simangunsong, A. H., \& Yuyeta, E. N. (2015). Analisis Pengaruh Komisaris Independen, Komite Audit Dan Kualitas Audit Terhadap Manajemen Laba Sebelum Dan Sesudah Adopsi IFRS (Studi Empiris Pada Perusahaan non-financial yang Terdaftar di Bursa Efek Indonesia). Diponegoro Journal Of Accounting.

Trilestari, D. I. (2020). Dewan Pengawas Syariah, Corporate Governance dan Kinerja Bank Syariah.

Umardani, D., \& Muchlish, A. (2017). Analisis Perbandingan Kinerja Keuangan Bank Syariah Dan Bank Konvensional Di Indonesia. Jurnal manajemen dan pemasaran jasa.

Vivin, Y. A., \& Wahono, B. (2017). Analisis Perbandingan Kinerja Keuangan Bank Umum Syariah Dengan Bank Umum Konvensional Di Indonesia. Jurnal Riset Manajemen.

Wang, J., Chen, M. -H., Fang, C. Y., \& Tian, L. (2018). Does Board Size Matter for Taiwanese Hotel Performance? Agency Theory or Resource Dependence Theory. Cornell Hospitality Quarterly.

Winarmo, S. H. (2019). Analisis NPM, ROA, dan ROE dalam Mengukur Kinerja Keuangan. Jurnal STEI Ekonomi. 